\title{
Optimum Monetary Policy in European Monetary Union
}

\author{
Mehdi Pedram \\ Dept. of Economics, Alzahra University \\ Vanak Square, Tehran, Iran \\ Tel: 98-910-005-2325 E-mail:Mehdipedram@alzahra.ac.ir
}

Received: February 15, 2017 Accepted: March 15, 2017

doi:10.5296/ber.v7i1.10746 URL: https://doi.org/10.5296/ber.v7i1.10746

\begin{abstract}
The euro has been introduced to a region that contains many discrepancies and differences. While there are many countries with different business cycles, exerting a single monetary policy which favors all the countries is impossible. I will show that in a simple open macro model by using "weighted mean mechanism", monetary authorities can exert a common monetary policy to synchronize business cycles and to diminish loss functions in the member states. As we can see by using optimal monetary policy, the business cycles become much more stable and even in 2009 we do not see any recession for Germany and France. Although In this model between 2006 till 2012 the MU (Monetary Union) interest rate should be higher than the United States one, the agent's countries would be in boom rather recession. If MU interest rates in 2012 and 2013 were less than the actual ones, recession in two countries would change to boom for them.
\end{abstract}

Keywords: Monetary Union; Weighted mean mechanism; New Keynesian Model

JEL Classification: E430; E520

\section{Introduction}

Following Pedram and by searching the Euro Area data, I can assert that the euro has been introduced into a divergent region(Pedram, 2011). In 1999-2006 the growth of real GDP varied from 1.4percent for Germany to 8.8 for Ireland while in 2015 it was -0.3 for Greece and 8.5 percent for Ireland and the projection for 2016 would be -0.2 for Greece and 5.7 percent for Ireland. Total factor productivity growth in 1999-2006 varied from 3.2 for Slovak to -1.2 for Portugal while in 2015 it was -1.4 for Greece and 3.4 for Ireland. If we look at the growth of labor productivity (GDP per hour, annual average) these disparities will be resulted, too. In 1999-2006, the growth of labor productivity varied from 0.2 for Spain to 5.5 for Estonia and 2015 it varied from -3.0 for Greece to 3.3 for Malta and for 2016(projection) would be -1.8 for Greece and 3.8 for Ireland(Database $\left.{ }^{\mathrm{TM}}, 2016\right)$. So, as Krugman, I can 
conclude that single currency in Euro Area caused firms reallocate activities and increase specialization(Krugman, 1993). So, countries with different specialization will be desynchronized even if confronted by the same shocks. Mundell suggests that for a successful single currency area there should be some degree of convergence(Mundell, 1961). The euro has been introduced to a region that contains many discrepancies and differences. The euro experience shows us that divergent economic cycles persist. So, I can assert that euro area is not an optimum currency area, and there is not any sign of convergence in the euro area. While there are many countries with different business cycles, exerting a single monetary policy which favors all the countries is impossible. Countries confronting with excess demand prefer tight policies and those with low demand prefer expansionary policies. So, exerting a common monetary policy without considering the difficulties of asymmetry could cause wrong results. If the European Central Bank (ECB) can exert such a monetary policy that causes business cycles between member states of euro area become relatively coordinated, then the problem will be reduced. However, as Pedram concluded and because of moral hazard problems, employing some kind of interregional transfer payments from booming countries to countries confronting an adverse shock is undesirable(Pedram, 2011). So, the debate against some kind of European interregional transfers is usual(Melitz, 1997). So, the main objective of this paper is that in employing monetary policy, the ECB board should consider the difficulties of asymmetry. I will show that in a simple open macro model by using "weighted mean mechanism", monetary authorities can exert a common monetary policy to synchronize business cycles and to diminish loss functions in the member states. Based on "weighted mean mechanism", I will extract optimum weights by considering the interaction between national fiscal and monetary policies in one hand and the same monetary policy exerted independently by the ECB on the other hand(Pedram, 2011). By extracting optimal weights, none of each countries can influences on the ECB decision and the ECB board employs the optimal weights to make decision about the optimal monetary policy. The paper is as follows: in section 2, the model is introduced. In section 3, I compute the model to survey its quantitative importance and section 4 provides conclusion.

\section{The Model}

I introduce the model for small specialized economy with perfect capital mobility. This economy characterized by transitory shocks, it means that the economy is expected to return to its natural output level. So, it means some simple rules for expectations. If the exchange rate depreciates now, it is expected to appreciate to its normal level tomorrow. The assumption of perfect capital mobility and substitutability of domestic and foreign bonds means that the uncovered interest parity condition to be hold. That is:

$$
i=i^{f}+e^{e}{ }_{+1}-e \quad e=l_{n} E
$$

I assume that domestic central bank sets interest rate with the following policy function:

$$
\mathrm{i}=\mathrm{r}^{\mathrm{f}}+\pi_{+1}^{\mathrm{e}}+\mathrm{h}\left(\pi-\pi^{*}\right) \quad \mathrm{h}>0
$$

Now, I consider that agents are "weakly" rational and under inflation targeting, agents accept the inflation rate is to be equal the central bank official inflation target. It means that: 


$$
\pi_{+1}^{\mathrm{e}}=\pi^{\mathrm{e}}=\pi^{*}=\pi^{\mathrm{f}}=2(\text { percent })
$$

The assumption of regressive expectations for exchange rate says that:

$$
\mathrm{e}_{\mathrm{t}+1}^{\mathrm{e}}-\mathrm{e}_{\mathrm{t}}=\Theta\left(\overline{\mathrm{e}}_{\mathrm{t}}-\mathrm{e}_{\mathrm{t}}\right) \quad \Theta>0
$$

I assume that the normal exchange rate is last period actual rate:

$$
\overline{\mathrm{e}}_{\mathrm{t}}=\mathrm{e}_{\mathrm{t}-1}
$$

From (4) and (5) I can say:

$$
\Delta \mathrm{e}=\mathrm{e}_{\mathrm{t}}-\mathrm{e}_{\mathrm{t}-1}=-\Theta^{-1}\left(\mathrm{i}-\mathrm{i}^{\mathrm{f}}\right)
$$

Now, we can extract the aggregate demand curve for small open economy.

$$
\mathrm{Y}-\overline{\mathrm{Y}}=\beta_{1}\left(\mathrm{e}^{\mathrm{r}}-\overline{\mathrm{e}}^{\mathrm{r}}\right)-\beta_{2}(\mathrm{r}-\bar{r})+\beta_{3}(\mathrm{~g}-\overline{\mathrm{g}})+\beta_{4}\left(\mathrm{y}^{\mathrm{f}}-\overline{\mathrm{Y}}^{\mathrm{f}}\right)
$$

The notation bar over the variables shows the long run equilibrium value for that variable. All the variables except $r$ measured in natural logarithms, and all the $\beta$ coefficients are positive. Now, we want to show that there is a negative relation between domestic output and inflation. First, we know that:

$$
\mathrm{e}^{\mathrm{r}}=\mathrm{e}_{-1}^{\mathrm{r}}+\Delta \mathrm{e}+\pi^{\mathrm{f}}-\pi
$$

Second, from uncovered interest parity we can say:

$$
\mathrm{r}=\mathrm{i}-\pi_{+1}^{\mathrm{e}}=\mathrm{i}^{\mathrm{f}}-\pi_{+1}^{\mathrm{e}}+\Delta \mathrm{e}^{\mathrm{e}} \Delta \mathrm{e}^{\mathrm{e}}=\mathrm{e}_{+1}^{\mathrm{e}}-\mathrm{e}
$$

If we assume $\mathrm{e}^{\mathrm{r}}=0$, and $\bar{r}=\bar{r}^{\mathrm{f}}$, we can write aggregate demand curve for a small open economy:

$$
\mathrm{Y}-\overline{\mathrm{Y}}=\beta_{1}\left(\mathrm{e}_{-1}^{\mathrm{r}}+\Delta \mathrm{e}+\pi^{\mathrm{f}}-\pi\right)-\beta_{2}\left(\mathrm{i}^{\mathrm{f}}-\pi_{+1}^{\mathrm{e}}+\mathrm{e}_{+1}^{\mathrm{e}}-\mathrm{e}-\bar{r}^{\mathrm{f}}\right)+\hat{\mathrm{Z}}
$$

$\hat{\mathrm{Z}}=\beta_{3}(\mathrm{~g}-\overline{\mathrm{g}})+\beta_{4}\left(\mathrm{y}^{\mathrm{f}}-\overline{\mathrm{Y}}^{\mathrm{f}}\right)$

Inserting (1) and (6) into (10) and this fact that $i^{\mathrm{f}}-\pi^{\mathrm{e}}{ }_{+1}=\mathrm{i}^{\mathrm{f}}-\pi^{\mathrm{f}}=\mathrm{r}^{\mathrm{f}}$ we obtain:

$$
\begin{gathered}
\mathrm{Y}-\overline{\mathrm{Y}}=\beta_{1} \mathrm{e}_{-1}^{\mathrm{r}}-\beta_{1}^{\wedge}\left(\pi-\pi^{\mathrm{f}}\right)+\mathrm{z} \quad \hat{\beta}_{1}=\beta_{1}+\mathrm{h}\left(\beta_{2}+\mathrm{\Theta}^{-1} \beta_{1}\right) \\
\mathrm{Z}=-\beta_{2}\left(\mathrm{r}^{\mathrm{f}}-\bar{r}^{\mathrm{f}}\right)+\beta_{3}(\mathrm{~g}-\overline{\mathrm{g}})+\beta_{4}\left(\mathrm{y}^{\mathrm{f}}-\overline{\mathrm{Y}}^{\mathrm{f}}\right)
\end{gathered}
$$

We then drive the following AD curve:

$$
\pi=\pi^{\mathrm{f}}+\left(\beta_{1} / \hat{\beta}_{1}\right) \mathrm{e}_{-1}^{\mathrm{r}}-\left(1 / \hat{\beta}_{1}\right)(\mathrm{y}-\overline{\mathrm{Y}}-\mathrm{z})
$$

By inserting (2) into (6), we can obtain the dynamics of the real exchange rate:

$$
\Delta \mathrm{e}=-\mathrm{h}^{-1}\left(\pi-\pi^{\mathrm{f}}\right)
$$

By inserting (13) into (8), we get the result:

$$
\begin{gathered}
\mathrm{e}^{\mathrm{r}}=\mathrm{e}_{-1}^{\mathrm{r}}+\pi^{\mathrm{f}}-\pi+h \Theta^{-1}\left(\pi^{\mathrm{f}}-\pi\right) \\
\mathrm{e}^{\mathrm{r}}=\mathrm{e}_{-1}^{\mathrm{r}}+\left(1+\mathrm{h} \Theta^{-1}\right)\left(\pi^{\mathrm{f}}-\pi\right)
\end{gathered}
$$


To complete our model for open economy, we consider a "shirking" model of efficiency wages. We assume that firm managers resist a change in the ratio of their wage relative to the general wage. So, real exchange rate depreciation will not induce firm managers to change their nominal wage. So, this simplified efficiency wage model implies "relative wage resistance". Off-course, we assume the rate of unemployment benefit to be indexed to the general wage level. Now, if we make the symmetry assumption for all firms and price-setting behavior for them as monopolistically competitive firms, we can obtain a short- run aggregate supply curve of the form:

$$
\pi=\pi^{\mathrm{e}}+\gamma(\mathrm{y}-\overline{\mathrm{Y}})+\mathrm{s}
$$

Where "s" is a variable that captures the productivity supply shocks. Now, we can solve the model to obtain the equilibrium values for $(y-\bar{Y}),\left(\pi-\pi^{\mathrm{f}}\right)$ and $\mathrm{e}^{\mathrm{r}}$ for each country in the monetary union. By inserting (22) into (12) and considering that $\pi^{\mathrm{e}}=\pi^{\mathrm{f}}$, and the result into real exchange rate equation (21), we obtain:

$$
\begin{aligned}
& (\mathrm{Y}-\overline{\mathrm{Y}})^{*}=\left(\beta_{1} / \gamma \hat{\beta}_{1}+1\right) \mathrm{e}_{-1}^{\mathrm{r}}+\left(1 / \gamma \hat{\beta}_{1}+1\right) \mathrm{z}-\left(\beta_{1}{ }_{1} / \gamma \hat{\beta}_{1}{ }_{1}+1\right) \mathrm{s} \\
& \left(\pi-\pi^{\mathrm{f}}\right)^{*}=\left(\gamma \beta \beta_{1} / \gamma \hat{\beta}^{\wedge}+1\right) \mathrm{e}_{-1}^{\mathrm{r}}+\left(\gamma / \gamma \hat{\beta}^{\wedge}{ }_{1}+1\right) \mathrm{z}-\left(2 \gamma \beta^{\wedge}{ }_{1}+1 / \gamma \beta^{\wedge}{ }_{1}+1\right) \mathrm{s} \\
& \mathrm{e}^{\mathrm{r}^{*}}=\left\{\left(\gamma \beta^{\wedge}{ }_{1}+1-\left(1+\mathrm{h} \Theta^{-1}\right) \gamma \beta_{1}\right) /\left(\gamma \hat{\beta}^{\wedge}{ }_{1}+1\right)\right\} \mathrm{e}^{\mathrm{r}}{ }_{-1}-\left(1+\mathrm{h} \Theta^{-1}\right)\left(\gamma / \gamma \beta^{\wedge}{ }_{1}+1\right) \mathrm{z}+\left(1+\mathrm{h} \Theta^{-1}\right)\left(2 \gamma \beta^{\wedge}{ }_{1}+1 / \gamma \beta^{\wedge}{ }_{1}+1\right) \mathrm{s}
\end{aligned}
$$

Each country enters in the board of governors with the above structural model and the parameters that determine the characteristics of that country. As a member state in the ECB, it considers the inflation pressure, business cycles around the trend and real exchange rate fluctuations. So, it should compromise its own structure with the benefits of all monetary union, in other words, each country states the optimal monetary policy based on the country-specific situation. In this respect, we can obtain the equilibrium interest rate from the point of view of each member state and the ECB governors must exert such a policy which to be in favor of every member state and the whole union. If the governors exert weighted mean mechanism of these different views, none of each country can influence on the ECB board decision. So, we must change the monetary policy rule (2) in the following way:

$$
\mathrm{i}-\pi^{\mathrm{e}}{ }_{+1}=\mathrm{r}^{\mathrm{f}}+\left(\pi-\pi^{\mathrm{f}}\right)+\left(\mathrm{e}^{\mathrm{r}}-\mathrm{e}_{-1}^{\mathrm{r}}\right)+(\mathrm{y}-\overline{\mathrm{Y}})
$$

By using (23), (24), (25) and(3), the equilibrium interest rate from the point of view of each country and the whole MU (Monetary Union) obtains:

$$
\mathrm{i}=\mathrm{i}^{\mathrm{f}}+\left\{\beta_{1}\left(1+\mathrm{h} \gamma \Theta^{-1}\right) / \gamma \beta^{\wedge}+1\right\} \mathrm{e}^{\mathrm{r}}{ }_{-1}+\left(1+\mathrm{h} \gamma \Theta^{-1} / \gamma \hat{\beta}_{1}+1\right) \mathrm{z}-\left\{\hat{\beta}_{1}{ }_{1}+\mathrm{h} \Theta^{-1}\left(2 \gamma \hat{\beta}_{1}+1\right) / \gamma \beta_{1}{ }_{1}+1\right\} \mathrm{s}
$$

\section{A Quantitative Illustration}

In this section, I will calibrate the model to investigate quantitative importance of the model. First, by using equation (25), the equilibrium real effective exchange rate has been computed for Germany and France. For this computation, I assume $\mathrm{r}^{\mathrm{f}}=\bar{r}^{\mathrm{f}}$ and $\mathrm{y}^{\mathrm{f}}=\overline{\mathrm{Y}}^{\mathrm{f}}$. So, $(\mathrm{g}-\overline{\mathrm{g}})$ should be computed and for this, I have used the difference of growth rate of real value added in public administration, defense, education, human health and social activities from the mean for Germany and France separately. Off-course, I have assumed that the real effective 
exchange rate for 2000 has been considered as equilibrium one. Then, equation (27) has been used to compute equilibrium interest rate from the point of view of Germany and France separately. For this computation, I assume that $\mathrm{i}^{\mathrm{f}}$ is United States interest rate. It is worth to say that as long as the variable $\mathrm{s}$ is capturing random supply shocks, so, I assume that $\mathrm{E}(\mathrm{s})=$ 0 . In the next step, I have used "weighted mean mechanism" to compute equilibrium interest rate from the ECB board of governor's point of view. Then, based on equation (27) and ( $\mathrm{g}-\overline{\mathrm{g}})$ data for the whole MU, the equilibrium real effective exchange rate for the whole MU has been computed. In the last step, by using equations (23) and (24), and ( $\mathrm{g}-\overline{\mathrm{g}}$ ) data from Germany and France, the equilibrium $(Y-\bar{Y})^{*}$ and $\left(\pi-\pi^{\mathrm{f}}\right)^{*}$ have been computed for these two countries. It is worth to say that as long as equilibrium $\mathrm{i}^{\mathrm{mu}}$ considers the special situation of each country and constitute the characteristics of every member state, so is $\mathrm{e}^{\mathrm{rmu}}$ and the resulting $(\mathrm{Y}-\overline{\mathrm{Y}})^{*}$ and $\left(\pi-\pi^{\mathrm{f}}\right)^{*}$ are optimum for each country. To show that these are optimum values for these two countries, I have computed loss functions based on the following:

$$
\mathrm{E}(\mathrm{SL})=(\mathrm{h} / 2) \sigma_{\pi}^{2}+(\lambda / 2) \sigma_{\mathrm{y}}^{2}
$$

Loss functions of Germany and France for actual data were 3.3 percent and 10.93 percent respectively, but these loss functions for computed data became 0.15 and 0.17 percent for Germany and France. So, by considering asymmetries in exerting common monetary policy for the whole MU, it will be in favor of each member state and whole MU.

Tremosa-Balcells and Pons-Novell conclude that there are two different groups of countries which response differently to common monetary policy. While Germany is in one group, France is in another group(Tremosa-Balcells \& Pons-Novell, 2001).

In calibrating the parameters for Germany and France, I have used previous researches (Andersen, 2005; Coenen \& Wieland, 2005; Monticelli, 2003; Pedram, 2011; Svensson, 2000). Off-course for simplicity, I consider $\Theta=1$.

The parameters for France are: $\beta_{3}=0.3, \gamma=5, \beta_{1}=0.039, \mathrm{~h}=0.1, \mathrm{~h} \beta_{2}=0.0638, \lambda=10$.

The parameters for Germany are: $\beta_{3}=0.3, \gamma=1.25, \beta_{1}=0.039, \mathrm{~h}=1, \mathrm{~h} \beta_{2}=0.0947, \lambda=1$.

The parameters for monetary union are: $\beta_{3}=0.3, \gamma=2, \beta_{1}=0.039, \mathrm{~h}=0.2, \mathrm{~h} \beta_{2}=0.07$.

Figures 1and 2 show actual and computed real GDP growth rates for Germany and France. As we can see by using optimal monetary policy, the business cycles became much more stable and even in 2009 we do not see any recession for two countries. Figure 3 shows actual and computed long run interest rate for MU. The optimum policy dictates us to diminish interest rate from 2008 till 2014 much more less than actual one. This optimum policy causes to have boom rather recession except 2012 which the recession would be much more less than the actual data and in 2013 we would have confronted boom rather recession. Figure 4 shows: Although In this model between 2006 till 2012 the MU interest rate should be higher than the United States one, the agent's countries would be in boom rather recession. If MU interest rates in 2012 and 2013 were less than the actual ones, recession in two countries would change to boom for them. 


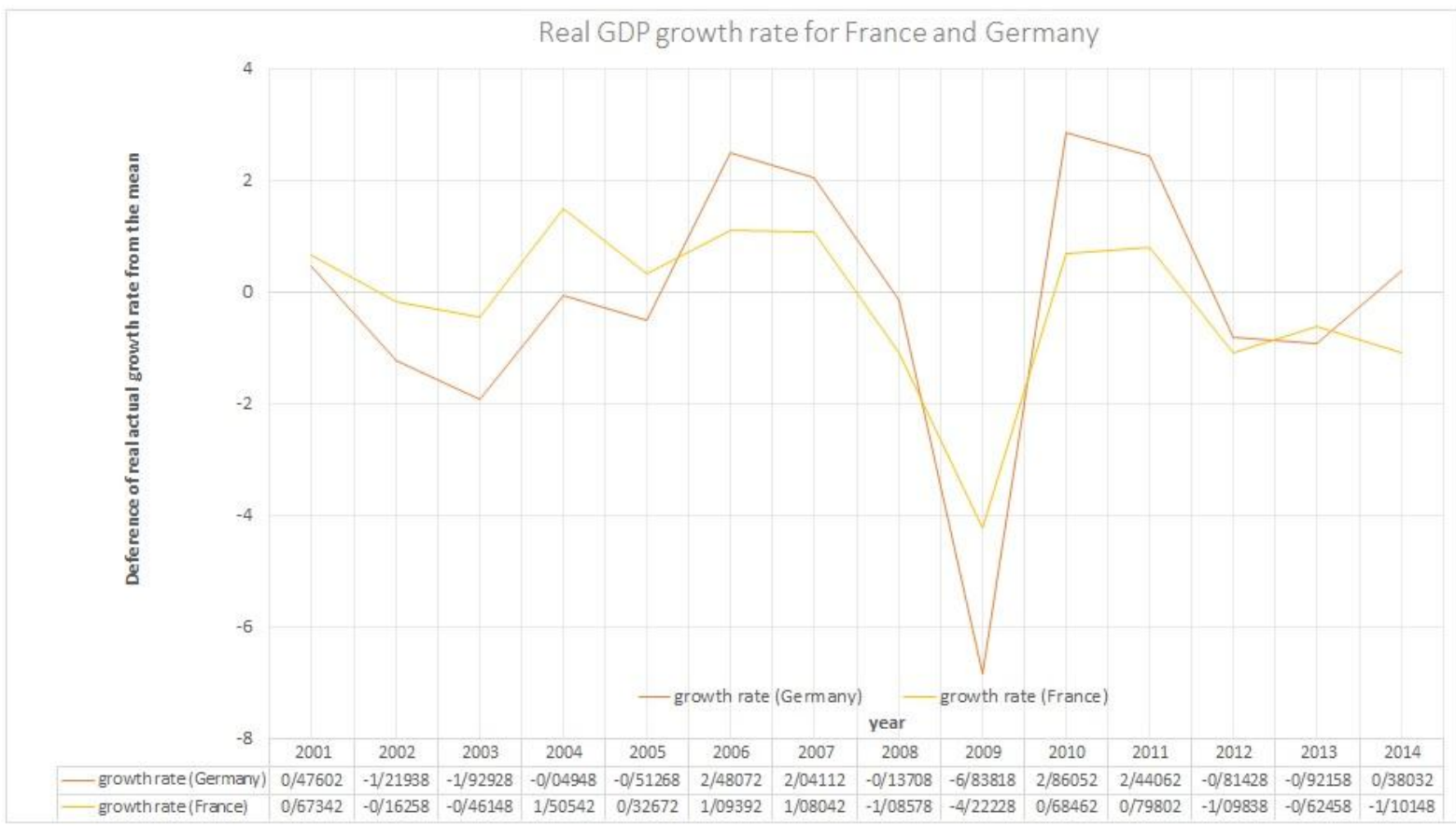

Figure 1. Real GDP Growth Rate for France and Germany(OECD)

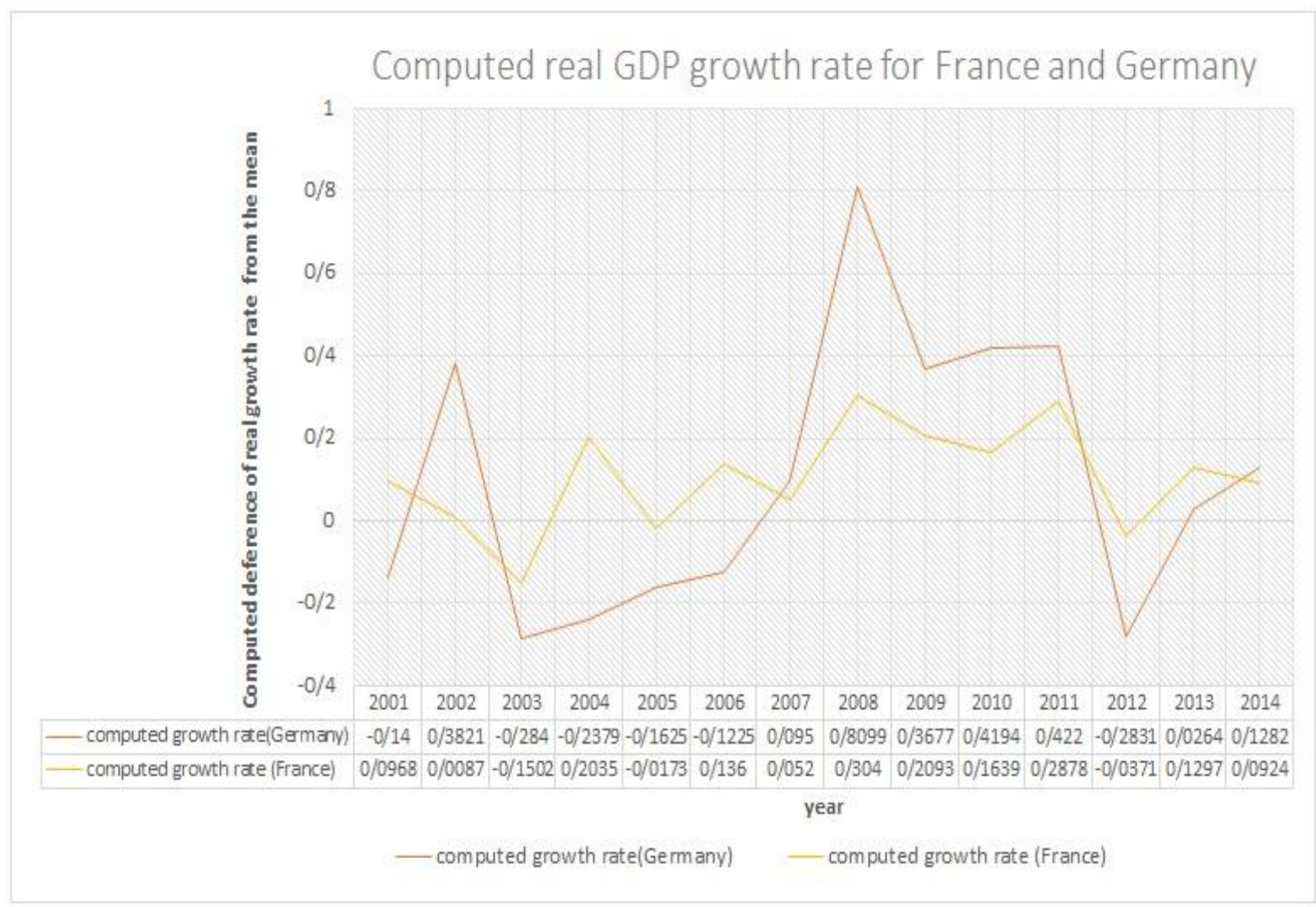

Figure 2. Computed Real GDP Growth Rate for France and Germany (Research computations) 


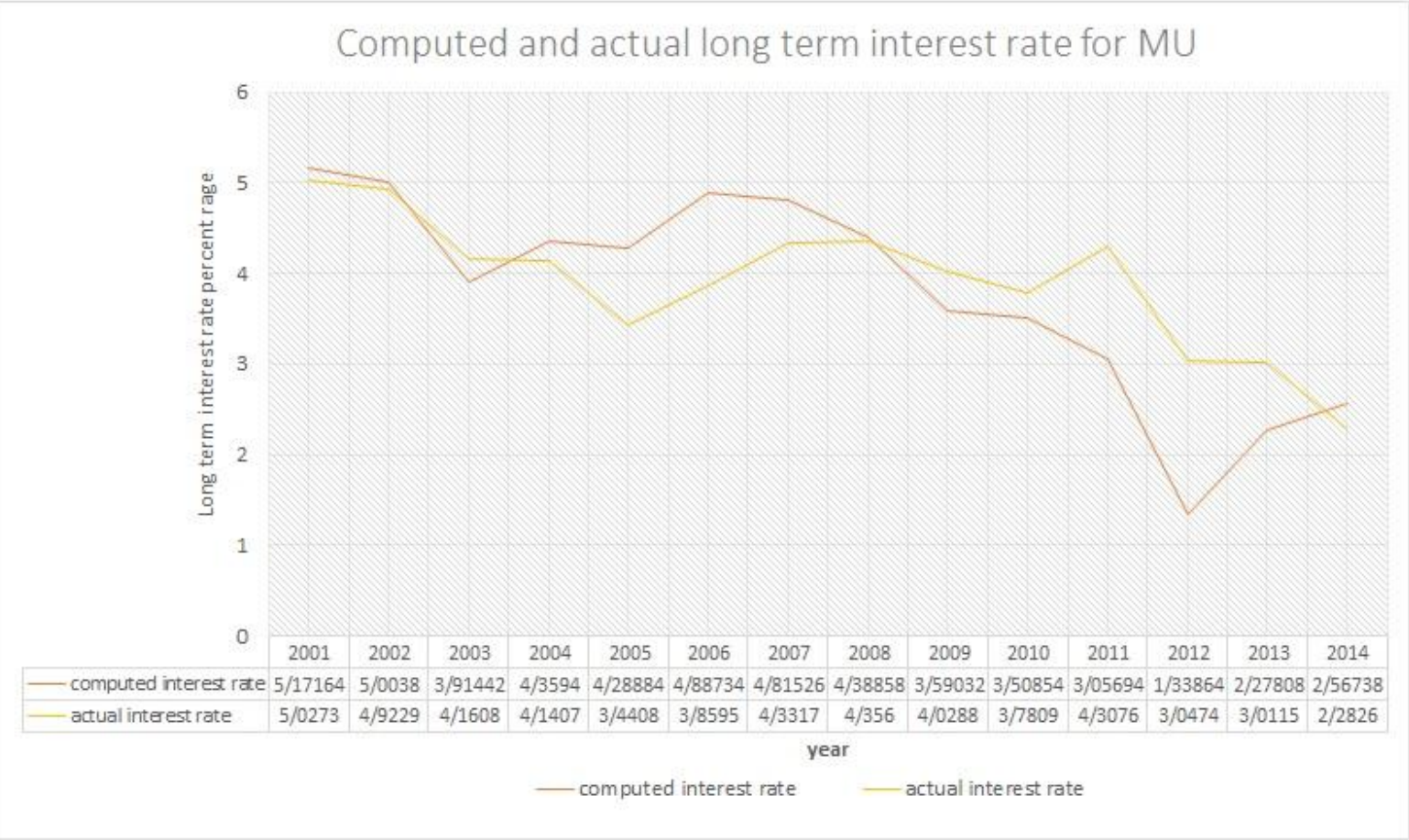

Figure 3. Computed and Actual Long Term Interest Rate for MU(OECD) and (Research computations)

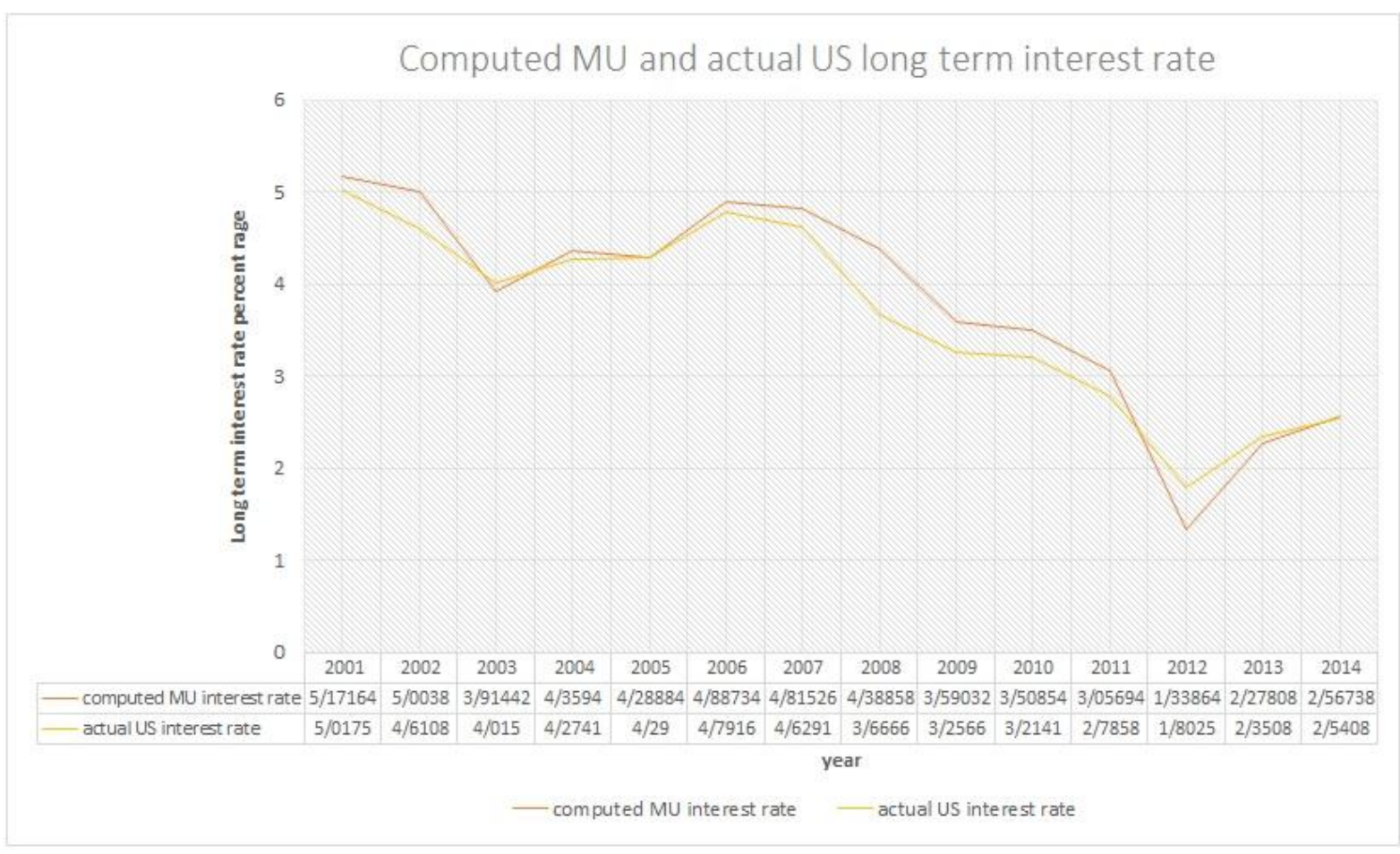

Figure 4. Computed MU and Actual US Long Term Interest Rate (OECD) and (Research computations) 


\section{Conclusion}

The optimum currency area should constitute convergent countries, but monetary union in Europe has formed by divergent countries. So, in exerting common monetary policy, the ECB should consider different asymmetries in MU. In this paper, "weighted mean mechanism" causes a common monetary policy which considers differences between countries of European monetary union. As we can see by using optimal monetary policy, the business cycles become much more stable and even in 2009 we do not see any recession for Germany and France. Although In this model between 2006 till 2012 the MU interest rate should be higher than the United States one, the agent's countries would be in boom rather recession. If MU interest rates in 2012 and 2013 were less than the actual ones, recession in two countries would change to boom for them.

\section{References}

Andersen, T. M. (2005). Fiscal stabilization policy in a monetary union with inflation targeting. Journal of Macroeconomics, 27(1), 1-29.

https://doi.org/10.1016/j.jmacro.2003.08.001

Coenen, G., \& Wieland, V. (2005). A small estimated euro area model with rational expectations and nominal rigidities. European Economic Review, 49(5), 1081-1104. https://doi.org/10.1016/j.euroecorev.2003.05.001

Database $^{\text {TM}}$, T. C. B. T. E. (2016). Total Economy Database. Retrieved 2017 Jan, from https://www.conference-board.org/retrievefile.cfm?filename=TED_SummaryTablesCharts_n ov2016.pdf\&type=subsite

Krugman, P. R. (1993). Lessons of Massachusetts for EMU. Adjustment and growth in the European Monetary Union, 241-261. https://doi.org/10.1017/CBO9780511599231.016

Melitz, J. (1997). The Evidence About Costs and Benefits of EMU. Swedish Economic Policy Review, 4(2), 359-410.

Monticelli, C. (2003). Voting on monetary policy in the Council of the European Central Bank. Economic Modelling, 20(5), 1015-1051.

https://doi.org/10.1016/S0264-9993(02)00063-9

Mundell, R. A. (1961). A theory of optimum currency areas. The American Economic Review, 51(4), 657-665.

OECD. OECD Factbook 2015-2016: OECD Publishing.

Pedram, M. (2011). Optimal monetary policy in the monetary union: effects on business cycles. OPEC Energy Review, 35(1), 90-117.

https://doi.org/10.1111/j.1753-0237.2010.00183.x

Svensson, L. E. (2000). Open-economy inflation targeting. Journal of international economics, 50(1), 155-183. https://doi.org/10.1016/S0022-1996(98)00078-6

Tremosa-Balcells, R., \& Pons-Novell, J. (2001). Measuring monetary policy shocks in the 


\section{Macrothink}

Business and Economic Research

ISSN 2162-4860 2017, Vol. 7, No. 1

European Monetary Union. Applied Economics Letters, 8(5), 299-303.

https://doi.org/10.1080/135048501750157440

\section{Copyright Disclaimer}

Copyright for this article is retained by the author(s), with first publication rights granted to the journal.

This is an open-access article distributed under the terms and conditions of the Creative Commons Attribution license (http://creativecommons.org/licenses/by/3.0/). 